Anita ADAMCZYK

Uniwersytet im. Adama Mickiewicza, Poznań

\title{
Dynamika zmian migracyjnych przed wejściem Polski do Unii Europejskiej
}

igracja do Polski była częścią ogólnoświatowych procesów, na które
praw człowieka.

Od początku lat 90. Polacy stali się świadkami zjawisk, których dotąd nie doświadczyli. Reformy społeczno-polityczne, otwarcie polskich granic, liberalizacja zasad wjazdu, jak również rozpoczęcie rozmów o członkostwo naszego kraju w strukturach Unii Europejskiej pociagnęło za sobą nieodwracalne zmiany w sferze społecznej, politycznej i ekonomicznej. Procesy migracyjne, które dotąd nas omijały stały się rzeczywistością. U progu XXI wieku stanęliśmy przed nowymi wyzwaniami. Związane były one z kwestiami dotyczącymi ochrony uchodźców, rozwoju przestępczości wśród obcokrajowców i nielegalnego przekraczania granic.

Na wzrost natężenia ruchów migracyjnych ze wschodu na zachód kontynentu wpłynęło załamanie się systemu socjalistycznego, powstanie nowych państw oraz postępujący proces globalizacji. W wielu krajach Europy Środkowo-Wschodniej migracje wewnętrzne zostały zastapione międzynarodowymi. Zwiększona ruchliwość ludzi podyktowana była również konfliktami na tle etnicznym i religijnym, wojnami i zamieszkami politycznymi, kryzysami ekonomicznymi oraz klęskami żywiołowymi. Innymi elementami, mającymi wpływ na skalę międzynarodowej migracji były czynniki: technologiczny (rozwój środków transportu i sieci komunikacyjnej umożliwiający łatwe i szybkie przemieszczanie się ludności, rozwój oraz upowszechnienie środków masowego przekazu), społeczno-ekonomiczny (rosnące dysproporcje w rozwoju gospodarczym i jakości życia między państwami rozwiniętymi a biednymi) ${ }^{1}$ oraz demograficzny (przeludnienie niektórych terenów).

Dynamika zmian migracyjnych w Polsce przypadła na okres po 1989 roku. Wówczas nastapił wzrost ruchów migracyjnych nie mający

1 W. Anioł, Migracje międzynarodowe a bezpieczeństwo europejskie, Warszawa 1992, s. 23-24. 
precedensu w historii naszego kraju. Początek ich sięgał 1990 roku, kiedy Polskę odwiedziło ponad 18210000 cudzoziemców (w porównaniu do roku poprzedniego liczba ta podniosła się o $220 \%$ ).

W kolejnych latach tendencja ta nie słabła (w 1991 roku polską granicę przekroczyło 36846000 cudzoziemców, trzy lata później ponad 74000 000, a w 1999 roku do kraju wjechała nie spotykana dotąd liczba obcokrajowców - 89117 900). Zmiany nastapiły dopiero w latach 2000-2002, gdy obserwowaliśmy spadek w ruchu osobowym cudzoziemców do Polski.

Ponowne ożywienie miało miejsce w okresie poprzedzającym wejście Polski do UE oraz w roku akcesji. Wpływ na tę sytuację miała większa liczba odwiedzających nas obywateli: Niemiec (wzrost o 34\% w 2004 roku w porównaniu do roku wcześniejszego), nowych krajów UE (wzrost o $11 \%$ ) oraz starych państw członkowskich (poza Niemcami - o 9\%) . $^{2}$ Przyrostowi zainteresowania wyżej wymienionych obywateli towarzyszył spadek przyjezdnych z Rosji, Białorusi i Ukrainy. O obniżeniu ich mobilności zadecydowało wprowadzenie wiz.

Saldo migracji w Polsce było ujemne. W latach 2000-2004 znacznie więcej Polaków opuszczało ojczyznę, niż przyjeżdżało do nas obcokrajowców.

Przyjazdy cudzoziemców do Polski w latach 1985-2004

Tabela 1

\begin{tabular}{||c|c|c|c||}
\hline Rok & $\begin{array}{c}\text { Przyjazdy cudzoziemców } \\
\text { do Polski }\end{array}$ & Rok & $\begin{array}{c}\text { Przyjazdy cudzoziemców } \\
\text { do Polski }\end{array}$ \\
\hline 1985 & 3410100 & 1995 & 82243600 \\
\hline 1986 & 3851000 & 1996 & 87438600 \\
\hline 1987 & 4776000 & 1997 & 87817400 \\
\hline 1988 & 6196000 & 1998 & 88592400 \\
\hline 1989 & 8233000 & 1999 & 89117900 \\
\hline 1990 & 18210800 & 2000 & 84514900 \\
\hline 1991 & 36846000 & 2001 & 61431300 \\
\hline 1992 & 49015000 & 2002 & 50734600 \\
\hline 1993 & 60951000 & 2003 & 52129800 \\
\hline 1994 & 74253000 & 2004 & 61917800 \\
\hline
\end{tabular}

Źródło: Turystyka w 2006 roku (www.stat.gov.pl - 4.05.2006); Statystyka SG: ruch graniczny, zwalczanie przestępczości, migracja. Podsumowanie działalności Straży Granicznej w 2001 roku; Statystyka SG: ruch graniczny, zwalczanie przestępczości, migracja. Podsumowanie działalności Straży Granicznej w 2002 roku, www.sg.gov.pl/informacje/index.asp?id=4 (15.12.2005).

2 Tabela 10.4, www.intur.com.pl/przyjazd.htm (4.07.2006). 
Wykres 1. Przyjazdy cudzoziemców do Polski w latach 1987-2004

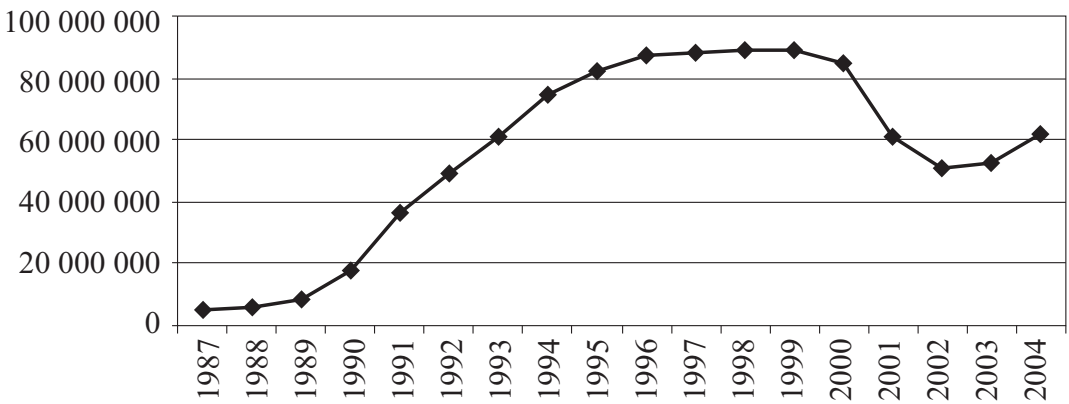

Spośród wielu narodowości odwiedzających Polskę najliczniejszą grupą byli Europejczycy, szczególnie Niemcy oraz obywatele byłego ZSRR (Ukraińcy). W latach 1990-1998 pierwsi z nich stanowili 25\% wszystkich cudzoziemców przybywających do RP, a drudzy (z części europejskiej byłego ZSRR) - 14,5\%. Znaczy udział w strukturze narodowościowej obcokrajowców mieli również Amerykanie $(15,6 \%)^{3}$ oraz Kanadyjczycy. Przed akcesją do Unii tendencja ta nie uległa zmianie.

Do Polski przyjeżdżali cudzoziemcy, którzy najczęściej legitymowali się wykształceniem średnim (między 1991-1998 rokiem stanowili oni $51 \%$ ) i wyższym (30\%). Stosunek liczby kobiet do mężczyzn był podobny (51,6\% - płeć męska, a 48,4\% - żeńska). Większość kobiet pochodziła z terenów byłego ZSRR, natomiast mężczyźni z Europy Zachodniej, USA, Afryki i Azji ${ }^{4}$.

Po 1990 roku Polska stała się dla wielu obcokrajowców państwem tranzytowym, jak również atrakcyjnym miejscem osiedlenia się. Cudzoziemcy najchętniej wybierali tereny uprzemysłowione i zurbanizowane. Preferowali przede wszystkim województwa: mazowieckie, małopolskie, śląskie i dolnośląskie ${ }^{5}$.

Imigranci decydowali się pozostać w Polsce, ponieważ zaostrzeniu uległy przepisy imigracyjne w państwach zachodnich oraz oczekiwaliśmy

3 D. Szymańska, E. Grzelak-Kostulska, Struktura i dynamika imigracji ludności do Polski w ostatniej dekadzie XX wieku, w: Wschodnia granica RP zewnętrzna granica Unii Europejskiej, pod red. J. Białocerkiewicza, Kętrzyn 2001, tab. 2, s. 91.

4 Ibidem, s. 90-91.

5 Migracje zagraniczne ludności 2002, GUS, Warszawa 2003, tab. 2. 
na wejście do struktur unijnych. Obcokrajowcy szukali spokoju, bezpieczeństwa oraz normalnego życia. Wśród cudzoziemców przebywających w Polsce pojawili się migranci: pozaekonomiczni (uchodźcy), ekonomiczni (planujący zostać u nas na krótki okres czasu lub na stałe), tranzytowi oraz zagraniczni studenci ${ }^{6}$ i turyści.

\section{Uchodźcy}

Dużym zaskoczeniem dla polskich władz, jak i społeczeństwa było pojawienie się w granicach naszego kraju uchodźców. Brak doświadczeń w zakresie udzielania im ochrony i opieki wywołało szereg problemów natury organizacyjnej, prawnej, socjalnej i finansowej. Sytuacja ta zmusiła polskie władze do szukania nowych rozwiązań.

Jednym z pierwszych kroków było przyjęcie szeregu dokumentów międzynarodowych, traktujących o ochronie tej grupy (np. Konwencji o statusie uchodźców z 28 lipca 1951 roku, Protokołu dotyczącego statusu uchodźców z 31 stycznia 1967 roku $^{7}$, Europejskiej Konwencji o Ochronie Praw Człowieka i Podstawowych Wolności z 4 listopada 1950 roku $^{8}$, a po akcesji do Unii Europejskiej - Rozporządzenia Rady Europejskiej nr 343/2003 z dnia 18 lutego 2003 roku ustanawiającego kryteria i mechanizmy określające państwo członkowskie odpowiedzialne za

6 Liczba studentów zagranicznych pobierających naukę do połowy lat 80 . nie przekraczała 3 tysięcy (w roku akademickim 1960/1961 w Polsce przebywało 740 studentów, w roku 1970/71 - 2576, a w roku 1985/86 - 2986). Wzrost odnotowano na początku lat 90., kiedy to w roku 1990/1991 grono studentów liczyło już 4259 osób. Na początku nowego stulecia liczba studiujących obcokrajowców przekroczyła 7000 (rok 2001/2002). Pochodzili oni z Europy (Ukrainy, Białorusi, Litwy, Rosji, Czech, Niemiec), następnie z Azji (Kazachstanu, Wietnamu). Najczęściej wybierano uniwersytety w Krakowie, Warszawie, Łodzi oraz Akademię Medyczną i Szkołę Główną Handlową w Warszawie. Studenci zagraniczni studiowali nauki społeczne, prawo, ekonomię, filologię i medycynę. ,Rocznik Statystyczny” za lata 1989, 1991, 2002; E. Jaroszewska, Studenci zagraniczni w Polsce z uwzględnieniem wyników badań przeprowadzonych na Uniwersytecie Warszawskim, w: Zewnętrzne migracje zarobkowe we współczesnej Polsce. Wybrane zagadnienia, pod red. A. Rajkiewicza, Włocławek 2000, s. 175-191.

7 Konwencja dotycząca statusu uchodźców, sporządzona w Genewie 28 lipca 1951 roku, Dz. U. 1991, Nr 119, poz. 515, Protokół dotyczący statusu uchodźców, sporządzony w Nowym Jorku 31 stycznia 1967 roku, Dz. U. 1991, Nr 119, poz. 517.

8 Europejska Konwencja o Ochronie Praw Człowieka i Podstawowych Wolności z 4 listopada 1950 roku, Dz. U. 1993, Nr 61, poz. 284. 
rozpatrzenie wniosku o nadanie statusu uchodźcy złożonego w jednym z państw członkowskich przez obywatela kraju trzeciego, tzw. Dublin II ${ }^{9}$ ).

Uznanie standardów międzynarodowych wpłynęło na zmiany w ustawodawstwie wewnętrznym. Dokonano najpierw nowelizacji ustawy o cudzoziemcach z 29 marca 1963 roku $^{10}$, a później przyjęto jej nową wersję ${ }^{11}$. Następnie zaakceptowano nowoczesne rozwiązania na poziomie Ustawy Zasadniczej $^{12}$ oraz uchwalono wiele ustaw i rozporządzeń regulujących kwestie pobytu i ochrony uchodźców w Polsce ${ }^{13}$.

9 Akt ten zastąpił konwencję wyznaczającą państwo odpowiedzialne za rozpatrywanie wniosków o azyl złożonych w jednym z Państw Członkowskich Wspólnoty Europejskiej, sporządzoną w Dublinie 15 czerwca 1990 roku. Treść dokumentu można znaleźć na stronie www.senat.gov.pl/k5/dok/SEJM/063/2641.pdf (12.11.2006).

10 Ustawa z dnia 19 września 1991 roku o zmianie ustawy o cudzoziemcach, Dz. U. 1991, Nr 119, poz. 513.

11 Ustawa z dnia 25 czerwca 1997 roku o cudzoziemcach, Dz. U. 1997, Nr 114, poz. 739 - obecnie zastąpiona ustawą z dnia 13 czerwca 2003 roku o cudzoziemcach, Dz. U. 2006, Nr 234, poz. 1694.

12 Konstytucja Rzeczypospolitej Polskiej z 2 kwietnia 1997 roku (art. 56 pkt 2), Dz. U. 1997, Nr 78, poz. 483.

13 Do nich zalicza się między innymi: Rozporządzenie Ministra Spraw Wewnętrznych i Administracji z dnia 14 sierpnia 2003 roku w sprawie wysokości pomocy dla cudzoziemców ubiegających się o nadanie statusu uchodźcy, Dz. U. 2003, Nr 146, poz. 1428; Rozporządzenie Ministra Spraw Wewnętrznych i Administracji z dnia 4 sierpnia 2003 roku w sprawie wzorów formularzy wniosków i wzorów dokumentów w postępowaniu o nadanie statusu uchodźcy, Dz. U. 2003, Nr 150, poz. 1458; Ustawa z dnia 13 czerwca 2003 roku o udzieleniu cudzoziemcom ochrony na terytorium Rzeczypospolitej Polskiej, Dz. U. 2003, Nr 128, poz. 1176 (tekst pierwotny), Dz. U. 2006, $\mathrm{Nr}$ 234, poz. 1695 (tekst jednolity); Rozporządzenie Ministra Spraw Wewnętrznych i Administracji z dnia 22 listopada 2002 roku zmieniające rozporządzenie w sprawie wysokości, warunków przyznawania i wstrzymywania oraz sposobu korzystania ze świadczeń dla cudzoziemców ubiegających się o nadanie statusu uchodźcy, Dz. U. 2002, $\mathrm{Nr}$ 203, poz. 1717; Rozporządzenie Ministra Spraw Wewnętrznych i Administracji z dnia 14 czerwca 2002 roku w sprawie postępowania wobec małoletnich cudzoziemców pozbawionych opieki w okresie postępowania o nadanie statusu uchodźcy, Dz. U. 2002, Nr 91, poz. 813 (uchylony z dniem 1.09.2003 roku); Rozporządzenie Ministra Spraw Wewnętrznych i Administracji z dnia 18 sierpnia 2003 roku w sprawie warunków zakwaterowania małoletnich bez opieki oraz standardu opieki w ośrodku dla cudzoziemców ubiegających się o nadanie statusu uchodźcy, Dz. U. 2003, Nr 151, poz. 1473; Rozporządzenie Ministra Zdrowia z dnia 17 marca 2003 roku w sprawie badań lekarskich oraz zabiegów sanitarnych ciała i odzieży cudzoziemców ubiegających się o nadanie statusu uchodźcy, Dz. U. 2003, Nr 61, poz. 553 (uchylony 2.09.2004 roku); Rozporządzenie Ministra Spraw Wewnętrznych i Administracji z dnia 21 stycznia 2002 roku w sprawie regulaminu pobytu w ośrodkach dla osób ubiegających się o nada- 
Konsekwencją przemian zachodzących w polityce państwa wobec uchodźców było budowanie odpowiednich struktur w ramach administracji państwowej. Geneza ich tworzenia sięga 1990 roku. Powołano wówczas Międzyresortowy Zespół ds. Pomocy Uchodźcom z Zagranicy, Międzyresortową Komisję ds. Uchodźców oraz Biuro Pełnomocnika Ministra Spraw Wewnętrznych ds. Uchodźców na czele z pułkownikiem Zbigniewem Skoczylasem (przekształcone 2 lutego 1993 roku w Biuro do Spraw Migracji i Uchodźstwa, a następnie w Departament do Spraw Migracji i Uchodźstwa działający w ramach Ministerstwa Spraw Wewnętrznych i Administracji, by w latach 1999-2001 zmienić jego nazwę na Departament Ochrony Granic, Migracji i Uchodźstwa).

W tworzonych od podstaw instytucjach ochrony uchodźców ukonstytuowały się także Rada do Spraw Uchodźców, która rozpoczęła swoją działalność na początku 1999 roku (jako organ administracji publicznej rozpatrujący odwołania i zażalenia od decyzji w zakresie nadania lub pozbawienia statusu uchodźcy) ${ }^{14}$ oraz Urząd ds. Repatriacji i Cudzoziemców (URiC) w 2001 roku $^{15}$.

nie statusu uchodźcy, Dz. U. 2002, Nr 10, poz. 105 (uchylony 1.09.2003 roku); Rozporządzenie Ministra Spraw Wewnętrznych i Administracji z dnia 12 sierpnia 2003 roku w sprawie regulaminu pobytu w ośrodkach dla cudzoziemców ubiegających się o nadanie statusu uchodźcy, Dz. U. 2003, Nr 146, poz. 1425; Rozporządzenie Ministra Spraw Wewnętrznych i Administracji z dnia 12 sierpnia 2003 roku w sprawie dokumentu podróży przewidzianego w Konwencji Genewskiej, Dz. U. 2003, Nr 150, poz. 1460; Ustawa z dnia 12 marca 2004 roku o pomocy społecznej, Dz. U. 2004, Nr 64, poz. 593; Ustawa z dnia 20 kwietnia 2004 roku o promocji zatrudnienia i instytucjach rynku pracy, Dz. U. 2004, $\mathrm{Nr}$ 99, poz. 1001; Ustawa z dnia 27 sierpnia 2004 roku o świadczeniach opieki zdrowotnej finansowanych ze środków publicznych, Dz. U. 2004, Nr 210, poz. 2135; Ustawa z dnia 28 listopada 2003 roku o świadczeniach rodzinnych, Dz. U. 2003, Nr 228, poz. 2255 (tekst pierwotny), Dz. U. 2006, Nr 139, poz. 992 (tekst jednolity z późniejszymi zmianami); Ustawa z dnia 13 czerwca 2003 roku o zatrudnieniu socjalnym, Dz. U. 2003, Nr 122, poz. 1143, Ustawa z dnia o szkolnictwie wyższym, Dz. U. 2005, Nr 164, poz. 1365; Ustawa z dnia 7 września 1991 roku o systemie oświaty, Dz. U. 1991, Nr 95, poz. 425 (tekst pierwotny), Dz. U. 2004, Nr 256, poz. 2572 (tekst pierwotny z późniejszymi zmianami).

14 Rozporządzenie Prezesa Rady Ministrów z dnia 20 stycznia 1999 roku w sprawie nadania Radzie do Spraw Uchodźców statutu organizacyjnego i regulaminu czynności wewnętrznych oraz określenia zasad wynagradzania ich członków, Dz. U. 1999, $\mathrm{Nr}$ 7, poz. 54 (uchylony 2.07.2002 roku); Rozporządzenie Prezesa Rady Ministrów z dnia 2 sierpnia 2002 roku w sprawie zasad wynagradzania członków Rady do Spraw Uchodźców oraz zwrotu innych kosztów ponoszonych w związku z pracą w Radzie do Spraw Uchodźców, Dz. U. 2002, Nr 126, poz. 1077 (uchylony 1.09.2004 roku).

15 Urząd ten powołano w wyniku nowelizacji ustawy z dnia 11 kwietnia 2001 roku o cudzoziemcach, rozdział 9a (Dz. U. 2001, Nr 127, poz. 1400). Uroczyste otwarcie 
Poza nimi powołano Biuro Łącznikowe Wysokiego Komisarza Narodów Zjednoczonych do Spraw Uchodźców, które w styczniu 1999 roku podniesiono do rangi Przedstawicielstwa oraz Biuro Organizacji Ośrodków dla Cudzoziemców Ubiegających się o Nadanie Statusu Uchodźcy lub Azylu. Był to organ odpowiedzialny za opiekę nad cudzoziemcami, objętymi procedurą statusową. Siedziba biura mieściła się w Centralnym Ośrodku Recepcyjnym dla Uchodźców w Podkowie Leśnej - Dębaku, które utworzono w 1992 roku. Podlegały jemu inne ośrodki pobytu uchodźców rozlokowane w województwach: lubelskim (Lublin, Niemce), lubuskim (Bezwola), mazowieckim (Warszawa, Smoszewo, Rudzianko, Łuków, Linin, Puste Łąki, Moszna, Dębak) i podlaskim (Białystok, Łomża, Czerwony Bór) ${ }^{16}$.

Koordynatorem działań w kwestiach związanych z uchodźcami były Ministerstwo Pracy i Polityki Społecznej, organizacje międzynarodowe oraz pozarządowe (Caritas Polska, Polska Akcja Humanitarna, Polski Czerwony Krzyż, Stowarzyszenie Uchodźców w RP, Stowarzyszenie Praw Człowieka im. Haliny Nieć).

Nowe rozwiązania prawne oraz instytucjonalne, mające na celu pomóc uchodźcom były bardzo potrzebne, bowiem rosła ich liczba w Polsce. Wpływ na tę sytuację miało szereg czynników. Do nich zaliczały się między innymi:

- zmiany demokratyczne w państwie polskim;

- rozwój ekonomiczny kraju;

- liberalizacja ruchu granicznego;

nastąpiło 29 czerwca 2001 roku. Statut Urzędu został określony w Rozporządzeniu Prezesa Rady Ministrów z dnia 29 czerwca 2001 roku w sprawie nadania statutu Urzędowi do Spraw Repatriacji i Cudzoziemców, Dz. U. 2001, Nr 67, poz. 686 (uchylony 1.09.2004 roku). Sytuację prawną tego urzędu regulowały ponadto: rozporządzenie Prezesa Rady Ministrów z dnia 22 sierpnia 2001 roku w sprawie zakresu i sposobu wyodrębniania składników majątkowych dla Urzędu do spraw Repatriacji i Cudzoziemców, pozostających dotychczas w trwałym zarządzie i używaniu Ministerstwa Spraw Wewnętrznych i Administracji (Dz. U. 2001, Nr 89, poz. 979) oraz ustawa z dnia 13 czerwca 2003 roku o cudzoziemcach (Dz. U. 2006, Nr 234, poz. 1694). Utworzenie tego centralnego organu administracji rządowej wiązało się z likwidacją Departamentu Migracji i Uchodźstwa MSWiA. Obecnie nosi on nazwę Urząd ds. Cudzoziemców (na podstawie Zarządzenia nr 82 Prezesa Rady Ministrów z dnia 3 sierpnia 2007 roku w sprawie nadania statutu Urzędowi do Spraw Cudzoziemców, M. P. 2007, Nr 48, poz. 567). Więcej na temat instytucji zajmujących się ochroną uchodźców czyt. A. Florczak, Uchodźcy w Polsce. Między humanitaryzmem a pragmatyzmem, Toruń 2003, s. 201-239.

16 www.udsc.gov.pl/Lista,osrodkow,dla,uchodzcow,464.html (5.04.2007). 
- zmiany polskiego ustawodawstwa (wprowadzenie instytucji uchodźcy) i przyjęcie zobowiązań, wynikających z przestrzegania międzynarodowych norm dotyczących ochrony praw człowieka i uchodźców;

- położenie Polski na szlaku migracyjnym biegnącym z Azji do Europy Zachodniej;

- napięcia i konflikty zbrojne;

- prześladowania i klęski żywiołowe;

- uznanie Polski jako bezpiecznego kraju trzeciego;

- perspektywa wejścia Polski do struktur unijnych.

Do lat 90. liczba osób szukających w Polsce schronienia była niewielka. Pierwsi uchodźcy pochodzili z Grecji i Chile. Po 1984 roku dołączyli do nich obywatele Palestyny, Libanu, Iranu, Iraku i niektórych państw z kontynentu afrykańskiego ${ }^{17}$. W 1990 roku, w wyniku deportacji azylantów przez władze Szwecji, do Polski trafili Etiopczycy, Somalijczycy, Libańczycy, Irakijczycy, Palestyńczycy. Wnioski o nadanie statusu uchodźcy złożyło wówczas 640 osób, z których otrzymało go $60 \%$, czyli 385 osób ${ }^{18}$. W następnym roku liczba cudzoziemców, występujących z wnioskami diametralnie wzrosła i przekroczyła już 2000 osób ${ }^{19}$. Należy podkreślić, iż był to rok, w którym Polska ratyfikowała Konwencję dotyczącą statusu uchodźcy z 1951 roku.

Dane statystyczne dotyczące problematyki uchodźstwa gromadzone były dopiero od 1992 roku. Zajmowało się tym Ministerstwo Spraw Wewnętrznych i Administracji. Z zebranych materiałów wynikało, iż w ciagu 12 lat (od 1992 do 2004 roku) o nadanie statusu uchodźcy w Polsce wystąpiło łącznie 45388 osób, z których status otrzymało 4,6\%, czyli 2100 wnioskujących (tab. 2).

17 W październiku 1984 roku PCK opiekowało się 46 osobami z Palestyny i Libanu (cześć z nich do końca tego roku opuściła granice naszego kraju). W lutym 1987 roku o pomoc do tej placówki zgłosiło się 38 Irańczyków (UNHCR przyznało im status uchodźcy i opuścili Polskę). Rok później ochrony poszukiwało 35 osób z Iranu, Iraku, Libanu, Etiopii, Angoli, Ghany, Sudanu, Turcji. Łącznie w latach 1984-1988 PCK udzieliło pomocy 320 cudzoziemcom. W 1989 roku liczba uchodźców urosła do 128. Cudzoziemcy poszukujacy ochrony w Polsce. Analiza danych zastanych, Raport pod kierunkiem G. Firlit-Fesnak, „Raporty Migracyjne” 2005, nr 6, s. 8-9. Szerzej na ten temat: M. Szonert, Rok 1990 - poczatki opieki nad uchodźcami. Migracje Polityczne XX wieku, „Migracje i Społeczeństwo” 2000, nr 4, s. 37.

18 Ibidem.

19 H. Grzymała-Moszczyńska, E. Nowicka, Goście i gospodarze. Problem adaptacji kulturowej $w$ obozach dla uchodźców oraz otaczajacych je społecznościach lokalnych, Kraków 1998, s. 28. 
Tabela 2

Liczba osób, które ubiegały się i otrzymały status uchodźcy w latach 1992-2004

\begin{tabular}{||c|c|c||}
\hline Rok & $\begin{array}{c}\text { Liczba osób składająca } \\
\text { wnioski o status uchodźcy }\end{array}$ & $\begin{array}{c}\text { Liczba osób, którym } \\
\text { przyznano status uchodźcy }\end{array}$ \\
\hline 1992 & 567 & 74 \\
\hline 1993 & 819 & 61 \\
\hline 1994 & 537 & 392 \\
\hline 1995 & 845 & 105 \\
\hline 1996 & 3210 & 120 \\
\hline 1997 & 3580 & 140 \\
\hline 1998 & 3423 & 55 \\
\hline 1999 & 3061 & 39 \\
\hline 2000 & 4662 & 53 \\
\hline 2001 & 4529 & 284 \\
\hline 2002 & 5170 & 253 \\
\hline 2003 & 6906 & 219 \\
\hline 2004 & 8079 & 305 \\
\hline Razem & 45388 & 2100 \\
\hline \hline
\end{tabular}

Źródło: www.udsc.gov.pl/Zestawienia,roczne,233.html, www.uric.gov.pl/statystyki.htm (5.04.2006).

W latach 1992-1995 liczba osób szukających w kraju schronienia nie była stabilna. Rocznie grupa wnioskodawców nie przekraczała 1000 osób. Później wzrosła (prawie 4-krotnie) i przez kolejne trzy lata utrzymywała się na poziomie 3000 rocznie. $W$ następnych miesiącach zainteresowanych statusem uchodźcy w Polsce było coraz więcej. Zmiany ilościowe związane były między innymi z wybuchem nowego konfliktu w Czeczenii oraz z perspektywą wejścia Polski do UE (w 2004 roku obcokrajowcy złożyli ponad 8000 podań. Ilość tych wniosków była ponad 10-krotnie większa niż w 1994 roku. Miesiąc przed integracją liczba osób, ubiegających się o status wzrosła o 477 w porównaniu z marcem i wyniosła łącznie $982^{20}$. Podobna sytuacja miała miejsce we wrześniu 2004 roku, kiedy złożono 942 podania, pochodzące w 94\% od obywateli Rosji ${ }^{21}$ - głównie Czeczenów, szukających schronienia po ataku terrorystycznym z 1 września 2004 roku na szkołę w Biesłanie).

20 Dane statystyczne Urzędu ds. Repatriacji i Cudzoziemców.

21 Ibidem. 
Uchodźcy pochodzili przede wszystkim z Azji, Europy, Afryki i Ameryki Łacińskiej. Byli oni obywatelami około 100 różnych państw. Skład narodowościowy zmieniał się i odzwierciedlał mapę konfliktów na świecie (Bałkany, Czeczenia, Afganistan - szczególnie po ataku 11 września 2001 roku w USA, Sri Lanka, Górny Karabach) oraz miejsc, w których łamane były prawa człowieka. W latach 1992-1994 dominowali wnioskodawcy z Bośni-Hercegowiny, Jugosławii, Etiopii, Armenii i Iraku. W kolejnych okresach z: Sri Lanki, Afganistanu, Indii, Mołdowy i Iraku. Od 2000 roku prym wiedli Rosjanie ${ }^{22}$, którzy w latach 2001-2004 stanowili $70 \%$ ogólnej liczby osób występujących z wnioskami. Wśród obywateli Federacji Rosyjskiej dominowali Czeczenii ${ }^{23}$.

Rosjanie, w tym osoby narodowości czeczeńskiej, należeli także do grona imigrantów, którym najczęściej przyznawano status uchodźcy w Polsce (w latach 2001-2004 otrzymali 81,5\% ogólnej liczby przyznanych statusów). Poza nimi, od 2001 roku, uchodźcy pochodzili z Białorusi, Afganistanu i Somalii. Natomiast w latach 90. status otrzymywali najczęściej obywatele: Libanu, Etiopii, Afganistanu, Sri Lanki, Bośni-Hercegowiny i Somalii ${ }^{24}$.

Liczba pozytywnie rozpatrzonych wniosków w stosunku do złożonych, w latach 1992-2004, nie była wysoka, poza pewnymi wyjątkami. Dotyczyło to 1994 roku, kiedy aż 65\% wnioskujących otrzymało status uchodźcy.

Duża część wniosków składana była przez imigrantów, którzy w sposób nielegalny znaleźli się w naszym kraju. Najczęściej przekraczali oni polską granicę na odcinku z Litwą, Białorusią i Ukrainą. Dopiero po zatrzymaniu przez Straż Graniczną lub Policję podejmowali stosowną decyzję.

Poza osobami pełnoletnimi o status uchodźcy zabiegały również dzieci pozostawione bez opieki. W latach 1992-1995 ich liczebność wahała się w granicach od 20 do 40 rocznie. W 1996 roku podniosła się drastycznie osiągając poziom 409 (czyli w porównaniu z rokiem poprzednim 10-krotnie więcej), a rok później 461 wniosków (tab. 3$)^{25}$. Były to 24 miesiące, w których największa liczba dzieci wystapiła z podaniem o status uchodźcy w ciagu 13 lat. Następne lata przyniosły spadek nieletnich wnioskodawców i od 2002 do 2004 roku ich liczba oscylowała wokół 200 rocznie.

22 Ibidem.

23 W 2000 roku złożyli oni 966 wniosków (24 osobom przyznano status uchodźcy), w 2001 roku wnioskodawców było już 1324 (199), rok później 2938 (209), a w 2003 roku rekordowa liczba osób narodowości czeczeńskiej - 5333 (202). www.unhcr.pl/files/228/czeczeni\%20w\%20Polsce.doc (22.07.2004).

\footnotetext{
24 Ibidem oraz www.unhcr.pl/statystyki/wnioski_a_statusy_1992-2000.php (4.06.2005).

25 W. Trojan, Dzieci pozbawione..., op. cit., s. 52.
} 
Tabela 3

Liczba dzieci poniżej 18 roku życia starająca się o status uchodźcy w latach 1992-2004

\begin{tabular}{||c|c||}
\hline Rok & $\begin{array}{c}\text { Liczba dzieci poniżej 18 roku życia starająca się } \\
\text { o status uchodźcy }\end{array}$ \\
\hline 1992 & 23 \\
\hline 1993 & 42 \\
\hline 1994 & 20 \\
\hline 1995 & 40 \\
\hline 1996 & 409 \\
\hline 1997 & 461 \\
\hline 1998 & 297 \\
\hline 1999 & $50 *$ \\
\hline 2000 & 69 \\
\hline 2001 & 80 \\
\hline 2002 & 212 \\
\hline 2003 & 213 \\
\hline 2004 & 211 \\
\hline
\end{tabular}

Źródło: *wg danych pochodzących z artykułu M. Kolankiewicz (Dzieci cudzoziemskie bez opieki w Polsce, s. 16) w 1999 roku o status uchodźcy ubiegało się 101 dzieci. www.dzieckokrzywdzone.pl/UserFiles/File/kwartalnik12/12_lolankiewicz.pdf (4.05.2006). Natomiast W. Trojan w swoim artykule podał liczbę 50 dzieci, w: W. Trojan, Dzieci pozbawione opieki jako uchodźcy, w: Wschodnia granica RP zewnętrzna granica Unii Europejskiej, pod. red. J. Białocerkiewicza, Kętrzyn 2001, s. 52-53, www.unhcr-budapest.org/poland/index.php?option=com_content $\&$ task $=$ view $\&$ id $=88 \&$ Itemid $=48(17.07 .2006)$.

Dzieci, poniżej 13 lat, podczas trwania postępowania o nadanie statusu uchodźcy przebywały w ośrodkach opiekuńczo-wychowawczych (Pogotowie Opiekuńcze nr 2 w Warszawie, Dom Dziecka nr 9, 11 w Warszawie, Dom Małych Dzieci im. Ks. Baudouina w Warszawie). Starsi natomiast w miejscach przeznaczonych dla uchodźców (Centralny Ośrodek Recepcyjny dla Uchodźców w Podkowie Leśnej - Dębaku).

Według danych Urzędu do Spraw Repatriacji i Cudzoziemców w 2001 roku spośród 80 dzieci, starających o status uchodźcy, w ośrodkach mieszkało tylko $40^{26}$. Małoletni cudzoziemcy przebywający w Polsce bez opieki byli obywatelami 45 państw ${ }^{27}$. Wielu z nich było także bezpaństwowcami.

26 www.unhcr.pl/publikacje/zobcejziemi/nr15/4506_wniosków.php (22.08.2005).

27 W okresie od 1992 do 1994 roku najwięcej dzieci pochodziło z Bośni-Hercegowiny, Armenii i Jugosławii. Od 1995 roku skład narodowościowy trochę się zmienił 
Cudzoziemcy występujący z wnioskami o status uchodźcy traktowali bardzo często Polskę jako kraj tranzytowy. Część z nich zatrzymywała się na krótki okres, by później udać się w dalszą podróż do państw Europy Zachodniej (Niemiec, Holandii, Belgii). Dla większości marzeniem było „[...] stać się obywatelem bezpiecznego i bogatego kraju, założyć rodzinę lub sprowadzić ją z własnego kraju i nie wyróżniając się niczym od zwykłych ludzi spokojnie żyć" ${ }^{28}$.

Osobom, którym odmówiono nadania statusu uchodźcy stworzono nową możliwość pozostania na terenie Polski. Instytucją tą była zgoda na pobyt tolerowany. Pierwsi cudzoziemcy mogli z niej skorzystać po 1 września 2003 roku $^{29}$. Poza nimi zgoda ta mogła być przyznana także imigrantom, którym nie wydano zezwolenia na zamieszkanie na czas oznaczony lub, którym zagrożono wydaleniem. W ciagu 4 miesięcy 2003 roku skorzystało z tego 72 cudzoziemców, a w kolejnym roku już 1097 osób. Tym samym grono obcokrajowców, pozostających w naszym kraju zwiększyło się o 1169 osób.

Tabela 4

Liczba osób, które otrzymały zgodę na pobyt tolerowany wg typu sprawy w okresie od września 2003 roku do końca 2004 roku

\begin{tabular}{||l|c|c|c|}
\hline \multicolumn{1}{|c|}{ Typ sprawy } & $\mathbf{0 9 - 1 2 . 2 0 0 3}$ & $\mathbf{2 0 0 4}$ & Razem \\
\hline Status uchodźcy & 24 & 846 & 870 \\
\hline Wydalenie & 21 & 210 & 231 \\
\hline Zezwolenie na zamieszkanie na czas oznaczony & 27 & 41 & 68 \\
\hline Razem & 72 & 1097 & 1169 \\
\hline
\end{tabular}

Źródło: Dane URiC.

W badanym okresie, pobyt tolerowany przyznano przede wszystkim obcokrajowcom, którzy otrzymali negatywną odpowiedź w sprawie przy-

i przeważały dzieci z Afganistanu, Sri Lanki i Bangladeszu. W ciągu dwóch ostatnich lat (2001-2002) o status uchodźcy aplikowały głównie dzieci z Afganistanu, Rosji, Republiki Mołdowy oraz Indii. Źródło: W. Trojan, Dzieci pozbawione..., op. cit., s. 52-53, www.unhcr.pl/statystyki/2002.php, www.unhcr.pl/publikacje/zobcejziemi/nr15/4506_wniosków.php (5.05.2004).

${ }_{28}$ Między pieklem a rajem. Problemy adaptacji kulturowej uchodźców i imigrantów w Polsce, pod red. M. Ząbka, Warszawa 2002, s. 36.

29 Był to dzień wejścia w życie postanowień ustawy z dnia 13 czerwca 2003 roku o udzieleniu cudzoziemcom ochrony na terytorium Rzeczypospolitej Polskiej (art. 97-105), Dz. U. 2003, Nr 128, poz. 1176 (tekst pierwotny), Dz. U. 2006, Nr 234, poz. 1695 (tekst jednolity z późniejszymi zmianami). 
znania statusu uchodźcy (stanowili oni 74\%). Pochodzili oni z 25 państw. Największą reprezentację posiadali obywatele: Rosji (760 osób), potem Afganistanu (23), Iraku (12), Ukrainy i Turcji (po 10) ${ }^{30}$. Na drugim miejscu, pod względem liczby przyznanych zgód na pobyt, znalazły się osoby podlegające wydaleniu (20\%). Wśród nich prym wiedli: Wietnamczycy (60 osób), Ormianie (34), Ukraińcy (28) i Białorusini (12) ${ }^{31}$. Z instytucji tej skorzystało także 68 osób, którym odmówiono zezwolenia na zamieszkanie na czas oznaczony. Reprezentowali oni 17 krajów. Najliczniejszą grupę stanowili obywatele: Rosji (28), Armenii (14), Chin (6), Białorusi i Nigerii (po 4).

\section{Migranci ekonomiczni}

Częstym zjawiskiem w Polsce, pod koniec lat 90. i na początku nowego stulecia, były migracje krótkoterminowe. Dominowały one na terenach przygranicznych. Związane były z rozwijającym się handlem w tej części kraju, tranzytem przez terytorium Polski oraz przyjazdami turystycznymi ${ }^{32}$. Wśród cudzoziemców, których podróż do nas umotywowana była czynnikami ekonomicznymi należeli przede wszystkim Ukraińcy, Rosjanie i Białorusini. Ich częste i krótkie wizyty (trwające najczęściej od 1 do 3 miesięcy) podyktowane były niskimi kosztami przejazdu i bliską odległością. Poza handlem na bazarach i ulicach podejmowali oni także inne prace zarobkowe nie wymagające często wysokich kwalifikacji zawodowych. Kobiety trudniły się na przykład opieką nad dzieckiem, sprzątaniem mieszkania, a mężczyzn zatrudniano w budownictwie czy rolnictwie. Wykonywali oni pracę najczęściej bez wymaganego zezwolenia (niezgodnie z prawem).

Rozwojowi tzw. szarej strefy zatrudniania obcokrajowców w Polsce sprzyjała odpowiednio przygotowana infrastruktura, czyli baza noclegowa (hotele robotnicze, tanie prywatne kwatery) oraz działalność nielegalnych giełd pracy (w Piasecznie, Warszawie i jej okolicach - na Okęciu, w Legionowie i Warce) $)^{33}$.

30 Dane statystyczne URiC.

31 Ibidem.

32 W celach turystycznych, spośród grona naszych sąsiadów, najczęściej odwiedzali nas Niemcy oraz Czesi i Słowacy. Natomiast wśród narodów Europy Zachodniej dominowali: Francuzi, Brytyjczycy, Szwedzi, Holendrzy, Austriacy. Spoza Starego Kontynentu chętnie przyjeżdżali Amerykanie, w tym Polonia. Szerzej na ten temat: W. Bartoszewicz, Cele, motywy i formy przyjazdów do Polski w 1998 roku, Warszawa 1999.

33 R. Antoniewski, Przyczynek do badań nad nieformalnym rynkiem pracy cudzoziemców, „Prace Migracyjne” 1997, nr 3, s. 6. 
Wg Państwowej Inspekcji Pracy w Polsce mogło nielegalnie pracować od 100000 do 150000 cudzoziemców. Z kolei z szacunkowych danych Krajowego Urzędu Pracy wynikało, iż liczba ta mogła sięgać nawet $800000^{34}$.

W przeciwieństwie do szarej strefy, legalne zatrudnienie znajdowało znacznie mniej osób. Wbrew powszechnej opinii wejście naszego kraju do struktur europejskich nie wywołało masowego napływu cudzoziemców na rodzimy rynek pracy. Przyniosło jednak odpływ polskiej siły roboczej z kraju.

Od lat 90. polski rynek pracy przestał mieć charakter narodowy. Zatrudnienie zagranicznych pracowników oparte zostało na zezwoleniach (przed 1 stycznia 2002 roku były to zgody ${ }^{35}$ ) wydawanych w formach: indywidualnej i kontraktowych usług eksportowych. $\mathrm{Z}$ analizy danych statystycznych (tab. 5) wynikało, iż dominowała pierwsza forma zatrudnienia. Od 1995 do 2002 roku wykazywała ona tendencję wzrostową. Później zaczęła spadać i rok przed wejściem do UE indywidualnych zezwoleń wydano już 18 841, a w 2004 roku 12 381. Zjawisko to związane było między innymi z faktem, iż z dniem 1 maja 2004 roku obywatele Wielkiej Brytanii, Szwecji i Irlandii uzyskali nieograniczony dostęp do naszego rynku pracy (w II połowie 2004 roku ilość udzielonych zezwoleń była o 707 mniejsza niż w I półroczu) $)^{36}$.

Tabela 5

Liczba wydanych zgód/zezwoleń indywidualnych i w ramach usług eksportowych na pracę dla cudzoziemców w latach 1992-2004 (w liczbach bezwzględnych)

\begin{tabular}{||c|c|c|}
\hline Rok & $\begin{array}{c}\text { Liczba wydanych zgód/zezwoleń } \\
\text { na pracę cudzoziemców } \\
\text { - indywidualnie }\end{array}$ & $\begin{array}{c}\text { Liczba wydanych zgód/zezwoleń } \\
\text { na pracę cudzoziemców w ramach } \\
\text { usług eksportowych }\end{array}$ \\
\hline 1 & 2 & 3 \\
\hline 1992 & 11995 & brak danych \\
\hline 1993 & 9643 & 1694 \\
\hline 1994 & 9220 & 1963 \\
\hline
\end{tabular}

34 B. Wyżnikiewicz, Przyszłość rynków pracy w świetle porozumień z Schengen, w: Polska droga do Schengen. Opinie ekspertów, Warszawa 2001, s. 116.

35 Ustawa z dnia 22 czerwca 2001 roku o zmianie ustawy o zatrudnianiu i przeciwdziałaniu bezrobociu oraz ustawy o pomocy społecznej (Dz. U. 2001, Nr 89, poz. 973) wprowadziła zmiany w nazewnictwie decyzji administracyjnych wydawanych w związku z dopuszczeniem cudzoziemców do rodzimego rynku pracy. Dotychczasową zgodę na pracę zastapiono zezwoleniem na pracę.

36 Dane statystyczne Departamentu Rynku Pracy Ministerstwa Gospodarki i Pracy. 


\begin{tabular}{||c|c|c|}
\hline 1 & 2 & 3 \\
\hline 1995 & 10441 & 920 \\
\hline 1996 & 11915 & 1753 \\
\hline 1997 & 15307 & 2191 \\
\hline 1998 & 16928 & 3831 \\
\hline 1999 & 17116 & 3502 \\
\hline 2000 & 17802 & 1860 \\
\hline 2001 & 17038 & 2755 \\
\hline 2002 & 22776 & 1867 \\
\hline 2003 & 18841 & 990 \\
\hline 2004 & 12381 & 798 \\
\hline
\end{tabular}

Źródło: Z. Morecka, Zatrudnienie cudzoziemców w Polsce, w: Popyt na pracę cudzoziemców. Polska i jej sqsiedzi, pod red. S. Golinowskiej, Warszawa 2004, s. 139; J. Korczyńska, M. Duszczyk, Zapotrzebowanie na pracę cudzoziemców w Polsce. Próba analizy i wniosków dla polityki migracyjnej, Warszawa 2005.

Cudzoziemcy szukali pracy na obszarach zurbanizowanych, o niskiej stopie bezrobocia. Do atrakcyjnych regionów należało województwo mazowieckie (w tym Warszawa), gdzie wydawano rocznie około 50\% wszystkich zezwoleń indywidualnych na pracę dla cudzoziemców w skali całego kraju ${ }^{37}$. Kolejnymi były: dolnośląskie, śląskie i pomorskie.

Pracownicy zagraniczni legitymowali się najczęściej wyższym i średnim wykształceniem, co miało wpływ na wykonywany zawód. Wśród nich dominowali: menedżerowie firm zagranicznych (obywatele państw Europy Zachodniej), właściciele zakładów (Wietnamczycy i Chińczy$\mathrm{cy}^{38}$ ), eksperci, specjaliści oraz nauczyciele języków obcych (Brytyjczycy, Ukraińcy, Amerykanie). Wielu z nich było artystami estradowymi, sportowcami czy lekarzami medycyny naturalnej (Mongołowie).

W Polsce pracę podejmowali przede wszystkim Europejczycy. Największą grupę stanowili obywatele byłego ZSRR (Rosjanie, Białorusini). Poza nimi pracownicy pochodzili także z zachodniej części Europy - Niemiec, Wielkiej Brytanii i Francji. Zatrudnienie znaleźli ponadto:

37 www.wup.mazowsze.pl (12.11.2005).

38 Napływ Chińczyków do Polski związany był między innymi z podpisaniem umowy handlowej i gospodarczej w 1993 roku, z rozszerzającym się rynkiem zbytu i nowymi inwestycjami (w Wólce Kosowskiej pod Warszawą mieści się chińskie centrum handlu hurtowego). Rozwój współpracy ekonomicznej przyciągnął do Polski w 1993 roku 2500 obywateli Chin, a w pierwszej połowie 1994 roku już 6500 osób. B. Brach, Chiny pod Warszawa, ,Wprost”, nr 40, z 2.10.1994, s. 40. 
Wietnamczycy, Turcy oraz obywatele Indii ${ }^{39}$. Niewielka tylko ilość osób pochodziła z Ameryki Północnej i Południowej oraz Afryki.

Wśród migrantów ekonomicznych wyróżniali się Wietnamczycy i Ormianie, których peregrynacja kończyła się w Polsce. Poza obywatelami państw sąsiadujących z nami na wschodzie (Ukraińcami, Białorusinami, Rosjanami) należeli oni do cudzoziemców najczęściej decydujących się na osiedlenie się i zamieszkanie na czas oznaczony.

Pierwsi z nich stanowili jedną $\mathrm{z}$ największych grup cudzoziemskich w naszym kraju. Ich liczebność Ministerstwo Spraw Wewnętrznych i Administracji szacowało na 50 000, a przedstawiciele tej społeczności na około $20000^{40}$.

Osadnicy z Wietnamu przybyli do Polski już w latach 60. i 70. Ich celem podróży była wówczas kontynuacja nauki. Druga fala migracji nastąpiła w latach 90. i miała już podłoże ekonomiczne ${ }^{41}$.

Wietnamczycy byli społecznością bardzo dobrze zorganizowaną. Posiadali własne organizacje (np. Stowarzyszenie Społeczno-Kulturalne Wietnamczyków w Polsce, Stowarzyszenie Wietnamczyków w Polsce „Solidarność i Przyjaźń”, Stowarzyszenie Przedsiębiorców Wietnamskich w Polsce), wydali rodzimą prasę („Bom Tin” - co znaczy „Wiadomości”, które w listopadzie 1999 roku zmieniło nazwę na „Que Viet”, czyli „Rodzimy Wietnam”, poza tym ukazywał się Dodatek Kulturalny „Van Viet” - „Kultura Wietnamska” ${ }^{42}$. W celu zachowania swojej tożsamości narodowej obchodzili najważniejsze święta wietnamskie, takie jak buddyjski Nowy Rok (Święto Tet), Dzień Niepodległości Wietnamu, Dzień Dziecka, Święto Zmarłych, Dzień Kultury Wietnamskiej i inne ${ }^{43}$.

39 Na podstawie materiałów statystycznych Departamentu Rynku Pracy Ministerstwa Gospodarki i Pracy.

40 T. Halik, E. Nowicka, Wietnamczycy w Polsce. Integracja czy izolacja?, Warszawa 2002, s. 24.

41 Część Wietnamczyków pod koniec 1995 roku napłynęła do Polski również z terenów Niemiec. Wynikało to z realizacji umowy zawartej między rządami Niemiec i Wietnamu, która przewidywała odesłanie około 40000 obywateli Wietnamu do ich kraju macierzystego (pobyt w granicach państwa niemieckiego wynikał z umowy podpisanej między NRD i Wietnamem). W obawie przed wydaleniem część przeniosła się do Polski. G. Pawelczyk, J. Szczęsny, Viettown, ,Wprost”, nr 2, z 10.01.1999, s. 38.

42 T. Halik, Migracje a przeptyw wartości kulturowych-Wietnamczycy w Polsce, w: Kultury pozaeuropejskie a globalizacja. Zderzenia, pod red. J. Zdanowskiego, Warszawa 2000, s. 243.

43 T. Halik, E. Nowicka, Wietnamczycy w Polsce..., op. cit., s. 92-93. 
Mieszkali przeważnie w dużych aglomeracjach miejskich, trudniąc się handlem na bazarach lub prowadzeniem małych punktów gastronomicznych czy restauracji. Byli oni aktywni zawodowo, o czym świadczyła wzrastająca liczba osób legalnie pracujących. Wśród pracowników pochodzących z kontynentu azjatyckiego, Wietnamczycy stanowili największą grupę (na 40057 Azjatów z indywidualnymi zezwoleniami w latach 1995-2004, obywatelom Wietnamu przypadło 12390 zgód) ${ }^{44}$. Teresa Halik, badająca społeczność wietnamską w Polsce, uważała że nie mieli kłopotów z procesem adaptacji w nowej rzeczywistości. Anh Tuan Truongo podkreślał ponadto, że Wietnamczycy ,[...] starają się i potrafią przystosować do każdych warunków. Łatwo nawiązują kontakty z innymi nacjami $[\ldots]^{\prime \prime 45}$.

Przestępczość w środowisku wietnamskim utrzymywała się na niskim poziomie. W latach 1998-2004 podejrzanych było jedynie 392 obywateli Wietnamu, czyli 0,95\% ogólnej liczby podejrzanych cudzoziemców (tab. 6). Specjalizowali się w oszustwach oraz fałszerstwach gospodarczych, kryminalnych, jak i nielegalnym przekraczaniu granicy. Wietnamczycy, jak poinformował „Wprost”, posiadali w Polsce swoją mafię ${ }^{46}$.

Tabela 6

Wietnamczycy podejrzani o popelnienie przestępstw i pokrzywdzeni w latach 1998-2004 w stosunku do ogólnej liczby podejrzanych i pokrzywdzonych obcokrajowców

\begin{tabular}{||c|c|c||}
\hline Rok & $\begin{array}{c}\text { Liczba podejrzanych } \\
\text { (w stosunku do ogólnej liczby) }\end{array}$ & $\begin{array}{c}\text { Liczba pokrzywdzonych } \\
\text { (w stosunku do ogólnej liczby) }\end{array}$ \\
\hline 1 & 2 & 3 \\
\hline 1998 & $62(6390)$ & $39(7141)$ \\
\hline 1999 & $26(6017)$ & $22(6424)$ \\
\hline
\end{tabular}

${ }^{44}$ Obliczenia własne na podstawie: M. Jaworek, Zatrudnienie cudzoziemców w Polsce w 2001 r., „Rynek Pracy” 2002, nr 5-6, s. 81; M. Okólski, Recent trends in international migration Poland 1996, „Prace Migracyjne” 1997, nr 16, s. 52; M. Okólski, Recent trends in international migration Poland 1998, „Prace Migracyjne” 1999, nr 28, s. 49; M. Okólski, Recent trends in international migration Poland 1999, „Prace Migracyjne" 2000, nr 32, s. 50; M. Okólski, Recent trends in international migration Poland 2000, „Prace Migracyjne” 2000, nr 39, s. 56; E. Kępińska, M. Okólski, Recent trends in international migration Poland 2002, „Prace Migracyjne” 2002, nr 48, s. 65; materiałów Departamentu Rynku Pracy Ministerstwa Gospodarki i Pracy.

${ }^{45}$ Święto Tet, wietnamski Nowy Rok - Rok Kozy, Internetowy Magazyn T. Grycana, nr 29 (04.2003), www.wudang.cis.com.pl/tet_29.html (6.06.2005).

46 J. Knop, Mafia z importu, „Wprost”, nr 9, z 3.03.2002r., s. 42. 


\begin{tabular}{||c|c|c||}
\hline \hline 1 & 2 & 3 \\
\hline 2000 & $61(5106)$ & $22(6079)$ \\
\hline 2001 & $57(7061)$ & $22(4811)$ \\
\hline 2002 & $65(6815)$ & $16(4456)$ \\
\hline 2003 & $62(5591)$ & $15(4272)$ \\
\hline 2004 & $59(3870)$ & $38(4290)$ \\
\hline
\end{tabular}

Źródło: www.kgp.gov.pl/statys/cudzoz.htm (23.07.2006); A Siemaszko, B. Gruszczyńska, M. Marczewski, Atlas przestępczości 2, Warszawa 1999, s. 45, 55; A Siemaszko, B. Gruszczyńska, M. Marczewski, Atlas przestępczości 3, Warszawa 2003, s. 47, 57.

Poza Wietnamczykami na dłuższy pobyt w Polsce decydowali się także Ormianie. Głównym powodem ich emigracji były czynniki natury ekonomicznej oraz konflikty zbrojne.

Na początku lat 90. wizyty większości Ormian nie trwały długo. Przyjeżdżali oni w celach handlowych, po czym wracali do kraju. Jednakże trudna sytuacja w Armenii oraz rosnące koszty przejazdów wpłynęły na decyzję o pozostaniu w Polsce ${ }^{47}$.

Ich obecność w naszym państwie była najczęściej niezgodna z prawem. Chcąc zalegalizować swój pobyt Ormianie podejmowali różne decyzje. Jedni ubiegali się o status uchodźcy (tab. 7), a inni decydowali się na małżeństwa z Polakami ${ }^{48}$ lub występowali z wnioskami o zezwolenia na: zamieszkanie na czas oznaczony ${ }^{49}$, na osiedlenie $\operatorname{sie}^{50}$ i pobyt stały $^{51}$.

47 W. Łukowski, Czy Polska stanie się krajem imigracyjnym?, „Prace Migracyjne" 1997, nr 12.

48 Na przykład w: 1995 roku obywatele Armenii zawarli z Polakami 71 związków małżeńskich, 1996 roku - 92, 1997 roku - 117, 1998 roku - 195, a w 2004 roku - 90 małżeństw. Dane GUS; K. Iglicka, Trendy migracji do Polski ..., op. cit., tab. 5, s. 211.

49 Wnioskodawcami o zezwolenie na zamieszkanie na czas oznaczony było 7744 Ormian (w latach 1998-2004). Spośród nich 5622 otrzymało pozytywne decyzje. Opracowanie własne na podstawie danych z URiC.

50 Od 1998 do 2004 roku, 879 obywateli Armenii złożyło w tej sprawie wnioski, z których $61 \%$ została pozytywnie rozstrzygnięta. Opracowanie własne na podstawie danych z URiC.

51 Łącznie w latach 1992-2000, 407 Ormian otrzymało pozytywne decyzje w sprawie zezwolenia na pobyt stały na ogólną liczbę 18664 decyzji. Opracowanie własne na podstawie danych $\mathrm{z}$ URiC. 
Tabela 7

Liczba Ormian występująca z wnioskami o status uchodźcy w wybranych latach w stosunku do ogólnej liczby cudzoziemców aplikujących o ten status w latach 1994-2004

\begin{tabular}{||l|c|c|c|c|c|c|c|c|c|c|c||}
\hline \multicolumn{1}{|c|}{ Rok } & $\mathbf{1 9 9 4}$ & $\mathbf{1 9 9 5}$ & $\mathbf{1 9 9 6}$ & $\mathbf{1 9 9 7}$ & $\mathbf{1 9 9 8}$ & $\mathbf{1 9 9 9}$ & $\mathbf{2 0 0 0}$ & $\mathbf{2 0 0 1}$ & $\mathbf{2 0 0 2}$ & $\mathbf{2 0 0 3}$ & $\mathbf{2 0 0 4}$ \\
\hline $\begin{array}{l}\text { Liczba Ormian, skła- } \\
\text { dająca wnioski }\end{array}$ & 257 & 151 & 354 & 482 & 1007 & 888 & 844 & 638 & 224 & 104 & 18 \\
\hline $\begin{array}{l}\text { Lączna liczba osób } \\
\text { wnioskująca o status }\end{array}$ & 537 & 845 & 3210 & 3580 & 3424 & 3061 & 4662 & 4529 & 5170 & 6906 & 8079 \\
\hline
\end{tabular}

Źródło: www.udsc.gov.pl/Zestawienia,roczne,233.html, www.uric.gov.pl/statystyki.htm (5.04.2006).

Na miejsce zamieszkania Ormianie wybierali północno-wschodni region Polski. Najczęściej byli to ludzie dobrze wykształceni, którzy nie mogli się spełnić zawodowo w naszym kraju. Praca, którą wykonywali rzadko odpowiadała ich nabytym umiejętnościom i przygotowaniu zawodowemu.

\section{Przestępczość cudzoziemców jako niepożądane zjawisko zmian migracyjnych}

Obecność obywateli innych państw w naszym kraju wpłynęła na wzrost poczucia zagrożenia Polaków. Obawy dotyczyły zarówno wzrostu konkurencyjności na rynku pracy (napływ taniej siły roboczej), jak i obniżenia stopnia bezpieczeństwa. Miało to swoje uzasadnienie, bowiem coraz częściej cudzoziemcy znajdowali się w kręgu osób podejrzanych o popełnienie przestępstw w Polsce (w okresie 10 lat, licząc od 1982 roku liczba podejrzanych wzrosła ponad 30-krotnie z 216 do 6815).

W latach 80. stopień zagrożenia przestępczością ze strony obcokrajowców był niewielki. Dopiero otwarcie granic, zniesienie wiz do kraju przyciągnęło wielu nielegalnych imigrantów. Pojawienie się ich miało wpływ na wzrost przestępczości granicznej, kryminalnej i gospodarczej.

Udział cudzoziemców w ogólnej liczbie podejrzewanych o popełnienie przestępstw był jednak nieznaczny (w 1984 roku wyniósł 0,1\%, w 1988 roku -0,5\%, w 1991 roku - 0,8\%, w 1996 roku - 1,8\%, w 1997 roku $-2,02 \%$, w 1998 roku - 1,6\%. Później współczynnik ten malał i w 2004 roku wyniósł $0,6 \%)^{52}$.

52 I. Rzeplińska, Przestępczość cudzoziemców w Polsce, Warszawa 2000, s. 7; dane Komendy Głównej Policji. 
Wykres 2. Cudzoziemcy podejrzani o popelnienie przestępstw w latach 1989-2004

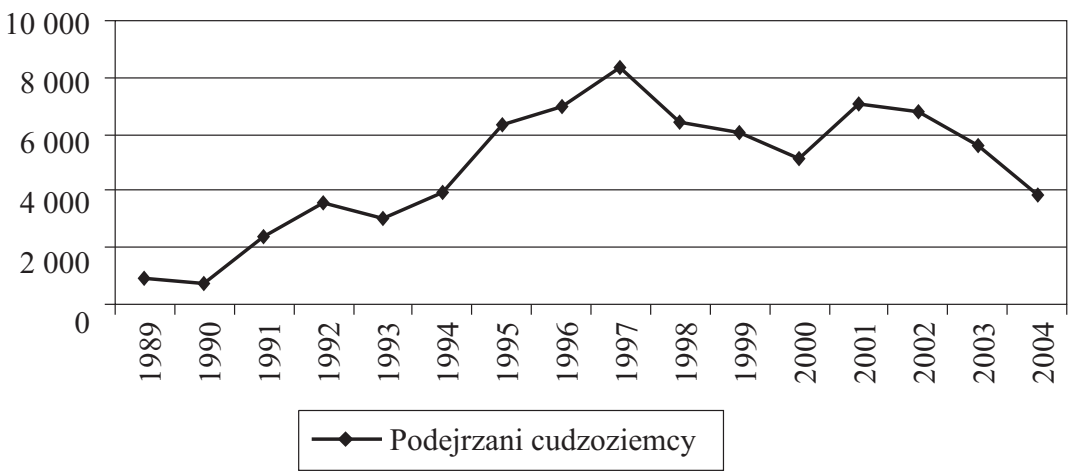

Źródło: Opracowanie własne na podstawie danych z: A Siemaszko, B. Gruszczyńska, M. Marczewski, Atlas przestęczości 2, Warszawa 1999, s. 45, 55; A Siemaszko, B. Gruszczyńska, M. Marczewski, Atlas przestępczości 3, Warszawa 2003, s. 47, 57.

Przestępczość obcokrajowców w Polsce była domeną tych narodowości, które nie wiązały swoich nadziei z naszym krajem. Należeli do nich cudzoziemcy przejeżdżający tranzytem przez nasz kraj oraz migranci ekonomiczni (podejmujący pracę sezonowo). Wśród grup narodowych najczęściej podejrzanymi byli: Ukraińcy, Białorusini, Rosjanie i Niemcy ${ }^{53}$.

Cudzoziemcy podejrzewani byli o popełnianie przestępstw pospolitych. W latach 1989-1999 najwięcej dokonali przestępstw drogowych (prym wiedli tutaj Niemcy i Ukraińcy) następnie kradzieży i kradzieży z włamaniami (dominowali Ukraińcy) oraz rozbojów i wymuszeń (obywatele Ukrainy oraz Białorusi $)^{54}$. Imigranci byli ponadto sprawcami przestępstw wymierzonych przeciwko życiu i zdrowiu ${ }^{55}$. Uczestniczyli także w przestępstwach akcyzowych, wynikających z naruszenia ustawy o oznaczeniu wyrobów znakami skarbowymi akcyzy z 1993 roku $^{56}$ (w 1996 roku

53 W latach 1989-2004, 24131 Ukraińców było podejrzanych o popełnienie przestępstwa. Na drugim miejscu uplasowali się Białorusini - 12828 podejrzanych. Na trzecim byli Rosjanie - 9587 osób, a na kolejnym Niemcy - 5871. Przestępczość w Polsce 1989-2000, Warszawa 2001, s. 128; http://www.policja.pl/portal/pol/4/319/ (3.04.2006).

54 www.policja.pl/statys/cudzoz.htm (17.09.2005).

55 Sprawcami ich byli najczęściej Ukraińcy. To oni, popełnili najwięcej zabójstw (w 1998 roku na 18 dokonali 9, a rok później - 10) i odpowiadali za uszkodzenia ciała oraz oskarżeni byli o pobicia lub bójki, ibidem.

56 Ustawa z dnia 2 grudnia 1993 roku o oznaczeniu wyrobów znakami skarbowymi akcyzy, Dz. U. 1993, Nr 127, poz. 584. Utraciła ona swą moc z dniem 1 maja 
co drugi cudzoziemiec w Polsce był o to podejrzany, rok później-42,4\%, a w 1998 roku $-43,7 \%{ }^{57}$ ).

W nowym stuleciu zakres czynów bezprawnych nie zmienił się. Nadal podejrzewano ich o popełnianie przestępstw: drogowych, akcyzowych, celnych oraz przeciwko życiu i zdrowiu. Dopuszczali się także fałszerstw kryminalnych i gospodarczych. W statystykach policyjnych figurowali, jako sprawcy rozbojów, kradzieży rozbójniczej i wymuszeń rozbójniczych.

Poza wyżej wymienionymi przestępstwami obywatele obcych państw brali także czynny udział w przestępczości zorganizowanej na terenie naszego kraju. Rozwojowi jej sprzyjała integracja europejska, znosząca bariery między państwami członkowskimi. Nie bez znaczenia były także położenie Polski między wschodem a zachodem Europy oraz czynniki ekonomiczne i społeczne.

Aktywność zorganizowanych grup o charakterze międzynarodowym i etnicznym skupiona była w dużych aglomeracjach miejskich (np. Warszawa, Gdańsk, Kraków) oraz terenach przygranicznych. Przybierała ona różne formy. W jej zakresie mieściła się przestępczość: graniczna, narkotykowa, gospodarcza oraz związana $\mathrm{z}$ fałszowaniem pieniędzy, nielegalnym handlem bronią i ludźmi.

Działalność ta przynosiła duże profity. Charakteryzowała się brutalnością i bezwzględnością jej członków. Jedną z dochodowych form było organizowanie nielegalnego przekraczania granicy. Procederem tym zajmowały się wyspecjalizowane grupy Polaków oraz cudzoziemców. Przemyt ludzi przez granicę odbywał się najczęściej w grupach kilkuosobowych. Trudno jednak ocenić, ile takich grup rocznie przekraczało granice. Wielkość tego zjawiska oszacować możemy jedynie na podstawie danych dotyczących liczby grup zatrzymanych na granicy państwowej (w 1998 roku ujawniono ich 387, w 2001 roku - 283, dwa lata później - 278, a w 2004 roku -267$)^{58}$. Z analizy materiałów Służby Granicznej wynikało, iż w latach 2000-2004 schwytano łącznie 1313 grup, liczących 10299 imigran-

2004 roku, po wejściu w życie ustawy z dnia 23 stycznia 2004 roku o podatku akcyzowym, Dz. U. 2004, Nr 29, poz. 257.

57 Przestępstwa te polegały na sprzedaży na przykład papierosów czy alkoholu bez akcyzy lub z przerobionymi, podrobionymi, uszkodzonymi znakami akcyzy. I. Rzeplińska, Przestęczość cudzoziemców..., op. cit., s. 18.

58 Statystyka SG: ruch graniczny, zwalczanie przestępczości, migracja. Podsumowanie działalności Straży Granicznej w 2002 roku, www.sg.gov.pl/informacje/index.asp?id=4 (12.11.2003); Podsumowanie działalności Straży Granicznej w 2004 roku, www.sg.gov.pl/informacje/index.asp?id=4 (22.04.2005). 
tów wraz z 890 osobami, które organizowały bądź udzielały pomocy przy przerzucie $^{59}$.

Zatrzymań dokonywano najczęściej na granicy lądowej. Głównym celem cudzoziemców było przedostanie się do Niemiec. Z tego powodu najwięcej przypadków usiłowania lub przekraczania nielegalnie granicy odnotowywano na odcinku polsko-niemieckim (w latach 1992-1996 współczynnik zatrzymań na zachodniej granicy wahał się od 70 do 90\% ogólnej liczby zatrzymanych przez Służby Graniczne na granicach kraju ${ }^{60}$ ). W mniejszym stopniu dotyczyło to granicy wschodniej i południowej ${ }^{61}$.

Nielegalna migracja odbywała się także poza przejściami granicznymi. Szczególnie było to widoczne w latach 90 . Wówczas liczba osób ujętych na zielonej granicy stanowiła 90\% (w 1991 i 1992 roku) i 70\% (w kolejnych latach do 1997 roku) ${ }^{62}$ ogólnej liczby zatrzymanych za usiłowanie lub nielegalne przekroczenie granicy. W nowym stuleciu współczynnik ten permanentnie się obniżał i najniższy pułap osiagnął w 2004 roku $-47 \%{ }^{63}$ (po 2001 roku zatrzymania częściej dokonywano na przejściach granicznych).

Wśród grup, trudniących się zorganizowaną przestępczością wyróżniały się te, w skład których wchodzili obywatele byłego ZSRR (Ukraińcy, Białorusini i Rosjanie - tabela 8).

Profity czerpali z kradzieży, handlu bronia, ludźmi oraz zabójstw na zlecenie, napadów i rozbojów drogowych ${ }^{64}$. W kręgu zainteresowań

59 Obliczenia własne na podstawie danych statystycznych Komendy Głównej Służby Granicznej.

60 A. Kowalski, Wybrane aspekty zwalczania przestęstw granicznych i przemytniczych popetnianych przez cudzoziemców na przejściach granicznych i na zielonej granicy, w: Przestepczość cudzoziemców. Nowe wyzwania dla teorii i praktyki, pod red. E. Pływaczewskiego, Szczytno 1995, s. 145; L. Sklepkowski, Polska jako kraj tranzytowy i docelowy nielegalnej migracji. Zorganizowane przerzuty przez granice, w: Polska policja wobec przestępczości zorganizowanej, pod red. W. Pływaczewskiego, J. Świerczewskiego, Szczytno 1997, s. 172.

${ }^{61}$ Więcej na ten temat w materiałach statystycznych Straży Granicznej (www.sg.gov.pl).

${ }^{6}$ K. Głąbicka, T. Halik, A. Sawicka, Studia nad przerzutem migrantów, „Prace Migracyjne" 1999, nr 23, tab. 2, s. 13.

63 Obliczenia własne na podstawie danych Straży Granicznej.

64 Więcej na ten temat w: J. Świeczyński, Cudzoziemcy jako sprawcy i ofiary przestęsstw w Polsce rosyjskojęzyczne grupy przestępcze, w: Polska policja wobec przestępczości zorganizowanej, pod red. W. Pływaczewskiego, J. Świerczewskiego, Szczytno 1997; K. Laskowska, Rosyjskojęzyczna przestępczość zorganizowana. Studium kryminologiczne, Białystok 2006; E. Pływaczewski, Problem sprawców tzw. ro- 
znajdowały się również przestępstwa przeciwko środkom płatniczym i dokumentom, przeciwko obrotowi gospodarczemu. Ofiarami grup rosyjskojęzycznych byli najczęściej ich rodacy.

Tabela 8

Udział obywateli rosyjskojęzycznych w zorganizowanych grupach przestępczych w latach 2000-2004

\begin{tabular}{||l|c|c|c|c|c|c||}
\hline \multicolumn{1}{|c|}{ Kraj pochodzenia } & $\mathbf{2 0 0 0}$ & $\mathbf{2 0 0 1}$ & $\mathbf{2 0 0 2}$ & $\mathbf{2 0 0 3}$ & $\mathbf{2 0 0 4}$ & Razem \\
\hline Rosja & 18 & 34 & 17 & 16 & 11 & 96 \\
\hline Ukraina & 28 & 64 & 60 & 52 & 38 & 242 \\
\hline Litwa & 5 & 17 & 19 & 22 & 23 & 86 \\
\hline Białoruś & 5 & 44 & 56 & 24 & 16 & 145 \\
\hline Pozostałe kraje b. ZSRR & 18 & 42 & 68 & 59 & 71 & 258 \\
\hline Razem & 74 & 201 & 220 & 173 & 159 & 827 \\
\hline
\end{tabular}

Źródlo: K. Laskowska, Rosyjskojęzyczna przestępczość zorganizowana. Studium kryminologiczne, Białystok 2006, tab. 1, s. 319.

Rozwój przestępczości zorganizowanej zmusił władze do podjęcia odpowiednich działań. Jednym z nich była centralizacja służb zajmujących się zwalczaniem tej przestępczości ${ }^{65}$. Istotne znaczenie miała także współpraca Straży Granicznej z Policją, urzędami celnymi, Agencją Bezpieczeństwa Wewnętrznego ${ }^{66}$ oraz koordynacja prac polskiej policji $\mathrm{z}$ jednostkami innych państw europejskich $\mathrm{w}$ tym zakresie $^{67}$. Inna sfera do-

syjskojęzycznych na tle przestępczości cudzoziemców w Polsce, w: U progu nowych kodyfikacji prawnych. Księga pamiatkowa ofiarowana prof. Leonowi Tyszkiewiczowi, pod red. O. Górniok, Katowice 1999.

65 W styczniu 1994 roku w Komendzie Głównej Policji uruchomiono Biuro do Spraw Przestępczości Zorganizowanej. Następnie na początku 1997 roku powołano Biuro do Spraw Narkotyków. W kwietniu 2000 roku połączono te dwa biura tworząc Centralne Biuro Śledcze.

${ }^{66}$ W ramach tej współpracy Komendant Główny Straży Granicznej podpisał: z Komendantem Głównym Policji porozumienie dotyczące zwalczania zorganizowanej przestępczości w dniu 15 czerwca 1998 roku oraz z Szefem Agencji Bezpieczeństwa Wewnętrznego porozumienie o współdziałaniu, którego zadaniem jest zapewnienie skuteczniejszego i sprawniejszego zwalczania nielegalnej migracji, terroryzmu oraz handlu, przemytu broni i materiałów niebezpiecznych (podpisane 10 czerwca 2003 roku).

67 Podstawą współpracy ze stroną niemiecką była Umowa z dnia 18 lutego 2002 roku między Rządem RP a Rządem Republiki Federalnej Niemiec o współpracy policji i straży granicznych na terenach przygranicznych, Dz. U. 2005, Nr 223, poz. 1915. 
tyczyła prac na poziomie legislacyjnym, w ramach których Polska zawarła z wieloma państwami umowy o współpracy w zakresie zapobiegania i zwalczania przestępczości zorganizowanej oraz innych przestępstw ${ }^{68}$, znowelizowała przepisy ustawodawstwa wewnętrznego oraz ratyfikowała dokumenty międzynarodowe ${ }^{69}$.

$$
* * *
$$

Natężenie ruchów migracyjnych w Polsce, od początku 1990 roku, było wynikiem zmian zachodzących na świecie. Rozwój demokracji, konflikty zbrojne, kryzysy ekonomiczne i polityczne miały swój udział w powiększającej się liczbie obcych przybywających do naszego kraju.

Dziś trudno jednoznacznie odpowiedzieć na pytanie czy Polska, wzorem innych państw, stanie się krajem imigracyjnym. Na razie z państwa typowo emigracyjnego przekształciliśmy się w emigracyjno-imigracyjne.

Po akcesji Polski do UE nasza wschodnia granica otrzymała status granicy zewnętrznej Unii. Stała się barierą, którą coraz trudniej pokonać obywatelom państw trzecich. Czynnikami odpychajacymi są nowe przepisy prawne regulujące zasady przekraczania polskiej granicy przez cudzoziemców (nie będących obywatelami UE) - wprowadzenie wiz, posiadanie określonych środków finansowych na pokrycie kosztów zakwaterowania, wyżywienia, przejazdu i wyjazdu z Polski ${ }^{70}$.

68 Umowy takie RP podpisała między innymi z: Republiką Federalną Niemiec (31 stycznia 1996 roku), Słowenią (28 sierpnia 1996 roku), Ukrainą (3 marca 1999 roku), Finlandią (4 listopada 1999 roku), Litwą (4 kwietnia 2000 roku), Belgią (13 listopada 2000 roku), Hiszpania (listopad 2000 roku), Irlandią (12 maja 2001 roku), Rumunią (11 lipca 2001 roku), Bułgarią (19 czerwca 2002 roku), Estonią (26 czerwca 2003 roku), Szwajcarią (deklaracja z 9 lipca 2003 roku), Wietnamem (28 lipca 2003 roku), Republiką Mołdowa (22 październik 2003 roku).

69 Jednym z nich było przystąpienie Polski do Konwencji Narodów Zjednoczonych przeciwko Międzynarodowej Przestępczości Zorganizowanej, przyjętej przez Zgromadzenie Ogólne Narodów Zjednoczonych dnia 15 listopada 2000 roku (Dz. U. 2005, $\mathrm{Nr} 18$, poz. 158).

70 Rozporządzenie Ministra Spraw Wewnętrznych i Administracji z dnia 29 września 2003 roku w sprawie wysokości środków finansowych, które powinien posiadać cudzoziemiec wjeżdżający na terytorium Rzeczypospolitej Polskiej i dokumentów, które mogą potwierdzić posiadanie tych środków oraz cel przekroczenia granicy, Dz. U. 2003, Nr 178, poz. 1748 (uchylone 6.12.2007 roku Rozporządzeniem Ministra 
Nielegalnej migracji nie sprzyja współpraca służb granicznych z Policją i jednostkami państw sąsiadujących. Częste kontrole legalności pobytu i zatrudnienia obcokrajowców zmniejszają liczbę osób niepożądanych. Istotne znaczenie $\mathrm{w}$ walce $\mathrm{z}$ przestępczością zorganizowaną i przekraczaniem granicy wbrew przepisom ma również włączenie Polski do systemów informacyjnych (Systemu Informacyjnego Schengen, Systemu Informacji Wizowej) oraz zawieranie umów o readmisji ${ }^{71}$.

Czy wyżej wymienione działania zahamują migrację do naszego kraju? Czy jedyne atuty Polski, jak atrakcyjne położenie oraz członkostwo w Unii Europejskiej będą wystarczającym magnesem dla wielu cudzoziemców, pokaże przyszłość.

\section{Summary}

The migration to and through Poland formed a part of global processes that were shaped by such factors as wars, poverty and the violation of human rights. Since the early 1990s, Poles have become the witnesses to phenomena they never experienced before. Social and political reforms, the opening of Polish borders, liberalization of entrance rules, and the beginning of the negotiations on Poland's membership in the EU structures brought about irreversible changes in the social, political and economic realms. The migration processes that used to bypass Poland have become a reality. In the beginning of the $21^{\text {st }}$ century we faced new challenges, related to the matters of refugee protection, increased crime rate among foreigners or illegal border crossing.

Spraw Wewnętrznych i Administracji z dnia 30 października 2007 roku w sprawie wysokości środków finansowych, które powinien posiadać cudzoziemiec wjeżdżający na terytorium Rzeczypospolitej Polskiej, oraz dokumenty, które mogą potwierdzić posiadanie tych środków, Dz. U. 2007, Nr 217, poz. 1616).

${ }^{71}$ Pierwsze porozumienie o readmisji Polska podpisała 29 marca 1991 roku z niektórymi państwami należącymi do grupy Schengen (Belgią, Francją, Holandia, Luksemburgiem, Niemcami, Włochami). Dwustronne umowy w tym zakresie rząd polski zawarł ponadto z: Republiką Czeską, Rumunią, Słowacją, Ukrainą, Niemcami, Bułgarią w 1993 roku, Grecja, Węgrami, Republiką Mołdowa, Chorwacją w 1994 roku, Słowenią w 1996 roku, Szwecją, Litwą w 1998 roku, Irlandią w 2001 roku. W latach 2000-2004 przekazano z Polski do innych państw łącznie 29778 osób, a przyjęto 10671 osób, z czego 93\% z terenów Niemiec. Obliczenia własne na podstawie Komendy Głównej Straży Granicznej. 
